\title{
Comparative study of post-partum intrauterine contraceptive device in vaginal and intra caesarean insertion
}

\author{
Babita Kanwat*, Lakshmi Salodia, Madhubala Chauhan, Radha Rastogi
}

Department of Obstetrics and Gynecology, RNT Medical College, Udaipur, Rajasthan, India

Received: 18 August 2017

Accepted: 16 September 2017

\author{
*Correspondence: \\ Dr. Babita Kanwat, \\ E-mail:drbabitam@gmail.com
}

Copyright: (C) the author(s), publisher and licensee Medip Academy. This is an open-access article distributed under the terms of the Creative Commons Attribution Non-Commercial License, which permits unrestricted non-commercial use, distribution, and reproduction in any medium, provided the original work is properly cited.

\begin{abstract}
Background: Institutional deliveries have increased all over the country, thereby providing opportunities for quality postpartum family planning services. In this period, women are highly receptive to accept family planning methods. Objective of this study was to evaluate CuT Multiload 375, in terms of acceptance, safety, efficacy, continuation rate, removal rate and to find out PPIUCD complications e.g. bleeding irregularities, perforation, expulsion and discontinuation due to various reasons.

Methods: Prospective analytical study was conducted from February 2016 to June 2016 in the department of Obstetrics and Gynecology, at RNT Medical College, Udaipur, Rajasthan, India.100 patients in each vaginal and cesarean group were selected randomly. Multiload 375 was inserted after obtaining written consent.

Results: Missing threads were detected more in cesarean group (22.8\%) than vaginal group (12.9\%). Cumulative expulsion rate was $15.2 \%$ in vaginal group and $10.8 \%$ in cesarean group. Heavy Bleeding PV with or without the pain was the main reason for removal of $\mathrm{CuT}$ in both the groups. Removal rate for vaginal and cesarean group was $15.2 \%$ and $10.8 \%$ respectively.

Conclusions: PPIUCD is very effective, safe and reversible contraceptive method which provides contraceptive effect soon after birth. Although there is relatively high incidence of expulsions and removal in the both group still the continuation rate was $69.4 \%$ in vaginal group and $78 \%$ in cesarean group.
\end{abstract}

Keywords: Continuation rate, Expulsion, Intra-cesarean insertion, Intrauterine contraceptive devices, PPIUCD, Post placental insertion

\section{INTRODUCTION}

Institutional deliveries have increased all over the country, thereby providing opportunities for quality postpartum family planning services. In this period, women are highly receptive and motivated to accept family planning methods. Ideally birth to birth interval is 36 months; but $61 \%$ of births in our country are shorter then recommended interval. $27 \%$ of births occur within 24 months, $34 \%$ births between 24 to 35 months after a previous birth. In the first postpartum year, $65 \%$ of women have an unmet need for family planning in our country. In this period only $26 \%$ of women are using any method of family planning. So healthy spacing of pregnancy must be achieved by postpartum family planning methods. ${ }^{1}$ Fear of complications and lack of information are the common problems for unmet need. ${ }^{2}$ Postpartum insertion of IUCD for spacing and limiting birth is very safe and effective approach, should be implemented in all deliveries ideally.

According to Medical Eligibility Criteria of WHO, an IUCD can be inserted within 48 hours postpartum or after 6 weeks following birth. Generally, it is not used between 48 hours to six weeks postpartum as there is increased chances of expulsion and infection (WHO category 3 ) as 
well as in puerperal sepsis and unresolved postpartum hemorrhage (WHO category 4$).^{3}$ Insertion of IUCD in postpartum period have various benefits over interval insertion. Advantage includes high motivation with surety the woman being not pregnant. Postpartum insertion avoids the discomfort during interval insertion and insertion related bleeding will be masked by lochia. ${ }^{4}$

Main purpose of this study was to compare risk and complication of PPIUCD in both vaginal and cesarean delivery groups and to assess the safety, feasibility, efficacy, expulsion, removal and continuation rate of postpartum IUCD insertion in the both group.

\section{METHODS}

Prospective analytical study was conducted from February 2016 to June 2016 in the Department of Obstetrics and Gynecology, at RNT Medical College, Udaipur, Rajasthan, India. Women were counseled during antenatal as well as early stage of labor regarding benefits and side effects of IUCD. 200 patients were selected randomly in vaginal (100) as well as cesarean deliveries (100). They were willing for follow up for 9 months. With informed written consent, $\mathrm{Cu}$ Multiload 375 was inserted in both groups. All eligible women fulfilling the following inclusion criteria were enrolled for study.

\section{Inclusion criteria}

- Desire to use Copper T 375 multiload for contraception

- Gestational age 34-40 weeks

- Given informed consent

- 18-40 years age

- Willing for follow up for 9 months.

\section{Exclusion criteria}

- $\quad$ Age $<18$ years $>40$ years

- Premature rupture of membrane $>18$ hours

- Severe anemia

- Antepartum haemorrhage

- Unresolved postpartum haemorrhage

- Puerperial sepsis

- Chorioamnionitis

- Intrauterine fetal death

- HIV not on antiretroviral therapy

- H/O trophoblastic diseases

- Known case of tuberculosis

- Diabetes and heart disease

- $\mathrm{H} / \mathrm{O}$ fever in the recent past

- Sexually transmitted diseases

- Uterine cavity distortion with fibroids and septa. ${ }^{3,5}$

Clinical details were collected as per a Pro forma. Detailed history was taken regarding her age, socioeconomic status, literacy, residence, religion, obstetrics history.

\section{Types of insertion}

\section{Post placental insertion}

Before starting the procedure, again ensured that woman has given the informed written consent and all the necessary sterile equipments were ready and available e.g. Multiload 375, Sims speculum, 2 ring forceps, povidine iodine, cotton swab and Kelley's placental forceps. Examination was carried out to rule out postpartum hemorrhage, extensive laceration and the uterine fundal height and its tone were also noted. Visualization of cervix was done by using Sim's speculum. Vaginal walls and cervix were cleaned twice with povidone iodine solution. Anterior lip of cervix was grasped with help of ring forceps till first lock. By using no touch technique, Multiload 375 was held with long placental forceps with edge only so that it can be easily released from the instrument when opened. By using the ring forceps, gentle traction applied on the anterior lip of cervix and IUCD was inserted into lower uterine cavity without touching the vaginal walls. Once the placental forceps reached into the lower uterine cavity, ring forceps was lowered, left hand was placed on suprapubic area and finger towards fundus. Uterus was gently pushed upwards to straighten the uterine cavity (for high fundal placement of IUCD) and ring forceps was removed. Placental forceps with IUCD moved upward until the fundus was reached when resistance was felt. Placental forceps was opened and slightly tilted inwards to release the CUT at fundus. Forceps must be opened and swept to right during withdrawal which ensured that instrument was away from the IUCD. Uterus was stabilized until forceps removal was complete. Lastly examination of cervix was done to ensure that thread of CUT was not visible at cervical os. (If it is visible then the IUCD has not been properly placed at the fundus and needs reinsertion)

\section{Intra-cesarean insertion of IUCD}

After stabilization of uterus, IUCD were placed manually high up at the fundus. CUT was held between the index and middle finger and inserted through the uterine incision. It was placed at fundus followed by slow withdrawal of hand taking care not to dislodge the IUCD. Strings were pointed towards the cervix but not pushed to the cervical canal to avoid contamination of uterine cavity by vaginal flora and to prevent displacement of IUCD. Precaution was taken to avoid strings to be included during uterine closure.

The participants were advised to return to hospital for scheduled follow up visit at 6 weeks, 3, 6 and 9 months or at any time in case excessive bleeding PV, pelvic pain, foul smelling discharge and with protrusion of $\mathrm{CuT}$ thread. At every visit, detailed clinical history was taken. 
Per speculum examination was done to check visibility of $\mathrm{CuT}$ thread. Excess of $\mathrm{CuT}$ threads were trimmed. Ultrasonography was done when CuT thread was not visualized.

\section{RESULTS}

Table 1 shows demographic distribution of the study population. Acceptance of PPIUCD, in this study was best in the age group of $21-25(60 \%$ in post placental and $53 \%$ in intra-cesarean) followed by $26-30$ years $(23 \%$ and $32 \%$ respectively).

Table 1: Socio-demographic and obstetrics characteristic of the study population.

\begin{tabular}{|c|c|c|}
\hline Characteristics & $\begin{array}{l}\text { Vaginal } \\
\text { insertion } \\
(n=100)\end{array}$ & $\begin{array}{l}\text { Intra- cesarean } \\
\text { insertion } \\
(n=100)\end{array}$ \\
\hline \multicolumn{3}{|l|}{ Age (years) } \\
\hline$<20$ & 7 & 10 \\
\hline $21-25$ & 60 & 53 \\
\hline $26-30$ & 23 & 32 \\
\hline $31-35$ & 9 & 5 \\
\hline$>35$ & 1 & 0 \\
\hline \multicolumn{3}{|l|}{ Residence } \\
\hline Urban & 14 & 22 \\
\hline Rural & 86 & 78 \\
\hline \multicolumn{3}{|l|}{ Parity } \\
\hline Para 1 & 25 & 26 \\
\hline Para 2 & 39 & 64 \\
\hline Para 3 & 25 & 10 \\
\hline Para 4 & 10 & 0 \\
\hline Para 5 & 1 & 0 \\
\hline \multicolumn{3}{|l|}{ Educational status } \\
\hline No formal education & 28 & 21 \\
\hline Primary education & 22 & 24 \\
\hline Secondary education & 37 & 28 \\
\hline Undergraduate & 5 & 15 \\
\hline Postgraduate & 8 & 12 \\
\hline \multicolumn{3}{|l|}{ Religion } \\
\hline Hindu & 93 & 94 \\
\hline Muslim & 7 & 6 \\
\hline \multicolumn{3}{|l|}{ Socio economic status } \\
\hline Low socio economic & 69 & 54 \\
\hline Middle socio economic & 30 & 45 \\
\hline High socioeconomic & 1 & 1 \\
\hline
\end{tabular}

Mean age of acceptance was comparable in the both groups, being $24.42 \pm 3.79$ years in vaginal and $24.20 \pm 3.42$ years in cesarean group. Patients from rural background were more motivated for PPIUCD than urban patients (86 and $78 \%$ in post placental and intra cesarean group respectively). Para 2 patients accepted PPIUCD more $(64 \%$ and $39 \%$ in intra-caesarean and post placental group respectively). Majority of cases belonged to low socioeconomic status $(69 \%$ in post placental and $54 \%$ in intra caesarean group). Acceptance was higher in patients with secondary education (37\% in post placental and $28 \%$ in intra caesarean group). Primary educated cases accepted PPIUCD in $22 \%$ of vaginal group and $24 \%$ of cesarean group. Significant numbers of cases were also belonged to no formal education ( $28 \%$ in vaginal and $21 \%$ in cesarean group). Undergraduate and postgraduate cases were higher in cesarean group as compared to vaginal group (15\% and $12 \%$ in comparison to $5 \%$ and $8 \%$ in cesarean and vaginal group respectively). Hindu women had higher acceptance as compared to Muslim (93\% and $94 \% \%$ Hindu in post placental and intra caesarean group respectively). Lost follow up was $15 \%$ in post placental insertion in comparison to $8 \%$ in intra cesarean insertion (Table 2).

Table 2: Follow up details.

\begin{tabular}{|c|c|c|}
\hline Follow up & $\begin{array}{l}\text { Post placental } \\
\text { group }(n=100)\end{array}$ & $\begin{array}{l}\text { Intra cesarean } \\
\text { group }(n=100)\end{array}$ \\
\hline $\begin{array}{l}\text { Return for } \\
\text { follow up }\end{array}$ & 85 & 92 \\
\hline In our clinic & 70 & 72 \\
\hline $\begin{array}{l}\text { Over phone (at } \\
\text { peripheral and } \\
\text { private hospital) }\end{array}$ & 15 & 20 \\
\hline Lost follow up & 15 & 8 \\
\hline
\end{tabular}

$42.3 \%$ of post placental group cases reported complaints related to $\mathrm{CuT}$ as compared to $38.0 \%$ in intra cesarean group. Protrusion of tail at introitus was complained by $14.1 \%$ in vaginal group whereas $7.6 \%$ in cesarean group. Lower abdominal pain was comparable in vaginal and intra cesarean group, $5.8 \%$ and $5.4 \%$ respectively.

Table 3: Complaints of cases at follow up.

\begin{tabular}{|llll|}
\hline Complaints & $\begin{array}{l}\text { Post } \\
\text { placental } \\
\text { group }(\mathrm{n}=85)\end{array}$ & $\begin{array}{l}\text { Intra } \\
\text { cesarean } \\
\text { group }(\mathrm{n}=92)\end{array}$ & $\begin{array}{l}\text { P } \\
\text { value }\end{array}$ \\
\hline $\begin{array}{l}\text { Protrusion } \\
\text { of tail at } \\
\text { introitus }\end{array}$ & $12(14.1 \%)$ & $7(7.6 \%)$ & 0.162 \\
\hline $\begin{array}{l}\text { Heavy } \\
\text { bleeding PV }\end{array}$ & $9(10.5 \%)$ & $8(8.6 \%)$ & 0.669 \\
\hline $\begin{array}{l}\text { Irregular } \\
\text { bleeding PV }\end{array}$ & $5(5.8 \%)$ & $9(9.7 \%)$ & 0.337 \\
\hline $\begin{array}{l}\text { Pain lower } \\
\text { abdomen }\end{array}$ & $5(5.8 \%)$ & $5(5.4 \%)$ & 0.897 \\
$\begin{array}{l}\text { White } \\
\text { discharge }\end{array}$ & $5(5.8 \%)$ & $6(6.5 \%)$ & 0.860 \\
\hline $\begin{array}{l}\text { Total no. of } \\
\text { cases having } \\
\text { complaints }\end{array}$ & $36(42.3 \%)$ & $35(38.0 \%)$ & 0.559 \\
\hline
\end{tabular}

Irregular vaginal bleeding was more in intra cesarean insertion $(9.7 \%)$ than vaginal group $(5.8 \%)$, while heavy and prolonged bleeding was more in post placental group $10.5 \%$ in comparison to $8.6 \%$ intra cesarean group. Unusual discharge per vagina complaint was not as higher as patients expected after IUCD insertion. 5.8\% 
cases in vaginal and $6.5 \%$ cases in cesarean group were complaining of vaginal discharge (Table 3 ).

Table 4: Examination findings at follow up visit.

\begin{tabular}{|c|c|c|c|c|c|}
\hline \multirow[t]{2}{*}{$\begin{array}{l}\text { Clinical } \\
\text { findings }\end{array}$} & \multicolumn{2}{|c|}{$\begin{array}{l}\text { Vaginal } \\
\text { group } \\
(\mathbf{N}=\mathbf{8 5})\end{array}$} & \multicolumn{2}{|c|}{$\begin{array}{l}\text { Intra } \\
\text { cesarean } \\
\text { group }(\mathrm{N}=92)\end{array}$} & \multirow[t]{2}{*}{$\begin{array}{l}P \\
\text { value }\end{array}$} \\
\hline & no. & $\%$ & no. & $\%$ & \\
\hline Missing tail & 11 & 12.9 & 25 & 22.8 & 0.019 \\
\hline $\begin{array}{l}\text { Protrusion of } \\
\text { tail at introitus } \\
\text { with IUCD in } \\
\text { situ }\end{array}$ & 5 & 5.8 & 2 & 2.1 & 0.206 \\
\hline $\begin{array}{l}\text { Displaced } \\
\text { IUCD (partial } \\
\text { expulsion) }\end{array}$ & 7 & 8.2 & 5 & 5.4 & 0.459 \\
\hline $\begin{array}{l}\text { Thread } \\
\text { trimming }\end{array}$ & 33 & 38.8 & 30 & 32.6 & 0.388 \\
\hline $\begin{array}{l}\text { Spontaneous } \\
\text { expulsion }\end{array}$ & 6 & 7.0 & 4 & 4.3 & 0.455 \\
\hline pregnancy & 0 & 0 & 0 & 0 & -- \\
\hline infection & 0 & 0 & 0 & 0 & -- \\
\hline Perforation & 0 & 0 & 0 & 0 & -- \\
\hline
\end{tabular}

Table 5: USG findings of PPIUCD clients.

\begin{tabular}{|llll|}
\hline USG findings & $\begin{array}{l}\text { Vaginal } \\
\text { group } \\
(\mathbf{n = 8 5})\end{array}$ & $\begin{array}{l}\text { Caesarean } \\
\text { group } \\
(\mathbf{n = 9 2})\end{array}$ & $\begin{array}{l}\mathbf{P} \\
\text { value }\end{array}$ \\
\hline $\begin{array}{l}\text { IUCD placed in } \\
\text { situ }\end{array}$ & $7(8.2 \%)$ & $23(25.0 \%)$ & 0.003 \\
\hline $\begin{array}{l}\text { IUCD in situ but } \\
\text { displaced } \\
\text { downwards }\end{array}$ & $0(0 \%)$ & $1(1.08 \%)$ & 0.355 \\
\hline $\begin{array}{l}\text { IUCD not } \\
\text { visualized in } \\
\text { cavity (absent) }\end{array}$ & $4(4.7 \%)$ & $1(1.08 \%)$ & 0.147 \\
$\begin{array}{l}\text { Total number of } \\
\text { cases requiring }\end{array}$ & $11(12.9 \%)$ & $25(27.1 \%)$ & 0.019 \\
\hline USG & & & \\
\hline
\end{tabular}

On first follow up, $38.8 \%$ of patients of vaginal group required trimming of the long threads as compared to $32.6 \%$ in intra cesarean group. Missing threads were detected more in cesarean group $22.8 \%$ than vaginal group $12.9 \%$. Ultrasound was conducted in $27.1 \%$ of cesarean and $12.9 \%$ in vaginal delivered patients mainly for missing tails (Table 5).

Table 6: Timing and rate of spontaneous and partial expulsion.

\begin{tabular}{|c|c|c|c|c|c|c|c|}
\hline \multirow[b]{2}{*}{$\begin{array}{l}\text { Timing of } \\
\text { expulsion }\end{array}$} & \multicolumn{3}{|c|}{ Post placental group (n=85) } & \multicolumn{3}{|c|}{ Intra cesarean group $(n=92)$} & \multirow[b]{2}{*}{$\begin{array}{l}\mathbf{P} \\
\text { value }\end{array}$} \\
\hline & $\begin{array}{l}\text { Spontaneous } \\
\text { expulsion }\end{array}$ & $\begin{array}{l}\text { Partial } \\
\text { expulsion }\end{array}$ & $\begin{array}{l}\text { Total } \\
\text { expulsion }\end{array}$ & $\begin{array}{l}\text { Spontaneous } \\
\text { expulsion }\end{array}$ & $\begin{array}{l}\text { Partial } \\
\text { expulsion }\end{array}$ & $\begin{array}{l}\text { Total } \\
\text { expulsion }\end{array}$ & \\
\hline$<7$ days & $1(1.1 \%)$ & - & $1(1.1 \%)$ & - & - & - & \multirow[t]{4}{*}{0.060} \\
\hline $\begin{array}{l}7 \text { days to } 2 \\
\text { months }\end{array}$ & $5(5.8 \%)$ & $6(7.0 \%)$ & $11(12.9 \%)$ & $1(1.0 \%)$ & $4(4.3 \%)$ & $5(5.4 \%)$ & \\
\hline $\begin{array}{l}2 \text { months to } 9 \\
\text { months }\end{array}$ & - & $1(1.1 \%)$ & $1(1.1 \%)$ & $3(3.2 \%)$ & $2(2.1 \%)$ & $5(5.4 \%)$ & \\
\hline $\begin{array}{l}\text { Total } \\
\text { expulsions }\end{array}$ & $6(7.0 \%)$ & $7(8.2 \%)$ & $13(15.2 \%)$ & $4(4.3 \%)$ & $6(6.5 \%)$ & $10(10.8 \%)$ & \\
\hline
\end{tabular}

Table 7: Reasons for removal of PPIUCD in both groups.

\begin{tabular}{|c|c|c|c|c|c|c|c|}
\hline $\begin{array}{l}\text { Reason of } \\
\text { removal }\end{array}$ & $\begin{array}{l}\text { Type of } \\
\text { insertion }\end{array}$ & $\begin{array}{l}\text { Removal at } \\
<6 \text { weeks }\end{array}$ & $\begin{array}{l}6 \text { weeks to } 3 \\
\text { months }\end{array}$ & $\begin{array}{l}3 \text { months to } \\
6 \text { months }\end{array}$ & $\begin{array}{l}6 \text { months to } \\
9 \text { months }\end{array}$ & Total & $\begin{array}{l}P \\
\text { value }\end{array}$ \\
\hline \multirow{2}{*}{$\begin{array}{l}\text { Heavy bleeding } \\
\text { PV }\end{array}$} & vaginal & $1(1.1 \%)$ & $1(1.1 \%)$ & & $3(3.5 \%)$ & $5(5.8 \%)$ & - \\
\hline & Intra cesarean & $1(1.0 \%)$ & & $1(1.0 \%)$ & $3(3.2 \%)$ & $5(5.4 \%)$ & - \\
\hline \multirow{2}{*}{$\begin{array}{l}\text { Irregular bleeding } \\
\text { PV }\end{array}$} & vaginal & & & & $1(1.1 \%)$ & $1(1.1 \%)$ & - \\
\hline & Intra cesarean & $1(1.0 \%)$ & $1(1.0 \%)$ & & & $2(2.1 \%)$ & - \\
\hline \multirow{2}{*}{$\begin{array}{l}\text { Heavy bleeding } \\
\text { PV with pain }\end{array}$} & Vaginal & & $2(2.3 \%)$ & & $1(1.1 \%)$ & $3(3.5 \%)$ & - \\
\hline & Intra cesarean & & & $2(2.1 \%)$ & $1(1.0 \%)$ & $3(3.2 \%)$ & - \\
\hline \multirow{2}{*}{$\begin{array}{l}\text { Abdominal } \\
\text { sterilization }\end{array}$} & vaginal & $1(1.1 \%)$ & & $1(1.1 \%)$ & $1(1.1 \%)$ & $3(3.5 \%)$ & - \\
\hline & Intra cesarean & & & & & & - \\
\hline \multirow{2}{*}{$\begin{array}{l}\text { Psychosocial } \\
\text { reason }\end{array}$} & vaginal & & $1(1.1 \%)$ & & & $1(1.1 \%)$ & - \\
\hline & Intra cesarean & & & & & & - \\
\hline \multirow{2}{*}{ Total removal } & vaginal & $2(2.3 \%)$ & $4(4.7 \%)$ & $1(1.1 \%)$ & $6(7.0 \%)$ & $13(15.2 \%)$ & \multirow{2}{*}{0.382} \\
\hline & Intra cesarean & $2(2.1 \%)$ & $1(1.0 \%)$ & $3(3.2 \%)$ & $4(4.3 \%)$ & $10(10.8 \%)$ & \\
\hline
\end{tabular}

Displaced IUCD were detected $8.2 \%$ in post placental group and $5.4 \%$ in the intra cesarean group (Table 4). Spontaneous expulsion of PPIUCD was reported in $7.0 \%$ of vaginal group and $4.3 \%$ of intra cesarean group. Similarly, partially expelled IUCD into the cervical canal were also higher in vaginal group $(8.2 \%)$ as compared to 
the intra cesarean $(6.5 \%)$ and these also included in expulsions (Table 6).

Removal of PPIUCD was done on account of heavy and irregular bleeding, abdominal pain, psychosocial reasons, and interval sterilization. Rate of removal was higher in post placental group (15.2\%) compared to cesarean group (10.8\%) (Table 7).

Table 8: Continuation rate in the study at 9 months.

\begin{tabular}{|c|c|c|c|c|}
\hline $\begin{array}{l}\text { Type of } \\
\text { insertion }\end{array}$ & Removal & Expulsions & $\begin{array}{l}\text { Continuation } \\
\text { rate }\end{array}$ & $\begin{array}{l}P \\
\text { value }\end{array}$ \\
\hline $\begin{array}{l}\text { Vaginal } \\
\text { insertion } \\
(n=85)\end{array}$ & $\begin{array}{l}13 \\
(15.2 \%)\end{array}$ & $\begin{array}{l}13 \\
(15.2 \%)\end{array}$ & $59(69.4 \%)$ & \\
\hline $\begin{array}{l}\text { Intra } \\
\text { cesarean } \\
\text { Insertion } \\
(n=92)\end{array}$ & $\begin{array}{l}10 \\
(10.8 \%)\end{array}$ & $\begin{array}{l}10 \\
(10.8 \%)\end{array}$ & $72(78.2 \%)$ & 0.180 \\
\hline
\end{tabular}

\section{DISCUSSION}

Unwanted pregnancy is still a major concern in our country. Family planning methods need to be strengthened to achieve limited family size to improve overall maternal and child health. PPIUCD seems to be a safe, long acting, easily accessible, highly effective and reversible contraceptive method for postpartum lactating women. It is best accepted by the parturient women who are unable to return to health care centers for contraceptive advice.

After counseling, $11.5 \%$ of post placental group and $11.23 \%$ of intra cesarean group accepted the PPIUCD insertion. Acceptance and actual insertion rates are not high because PPIUCD is still a new concept in the community. Majority of women who gave consent for PPIUCD belonged to the age group of $21-25$ years $(60 \%$ in post placental and 53\% in cesarean group) followed by 26-30 years $23 \%$ and $32 \%$ respectively This was probably because majority of the women who came to our tertiary hospital for delivery also belong to the same group. Halder et al also found that acceptance of PPIUCD was best in the age group of 21-25 years (40 and $44 \%$ in vaginal and intra cesarean group)) followed by $25-30$ years (31 and 23\%) (Table 1). ${ }^{6}$

Majority of the patients in the study group completed secondary school education $(37 \%$ and $28 \%$ in vaginal and cesarean group respectively) followed by primary education (22\% and $24 \%$ respectively). Most of the patients had completed at least primary school education (72\% and $79 \%$ in vaginal and cesarean group respectively). Significant numbers of cases were also belonged to no formal education $(28 \%$ in vaginal and $21 \%$ in cesarean group). Highly educated women were more in intra cesarean group $(27 \%)$ as compared to the vaginal group (13\%).
Results of present study revealed that acceptance is more in rural women (86 and $78 \%$ in post placental and cesarean group) as compared to urban (14 and 22\% respectively). PPIUCD were more accepted in less educated rural and low socioeconomic group (Table 1). This is probably because they are not aware of other methods of contraceptions, do not have transportation facility from remote areas, unavailability of peripheral health services and moreover no prefixed ideas regarding IUCD. Related social misbelieve in local community is more in urban and educated society. Proper information, motivation and guidance lead to high insertion in rural patients. Urban and higher educated women were more inclined towards the newer or modern method of contraception hence less interested in PPIUCD insertion. This is in contrast to majority of the studies where urban patient's acceptance was more than rural patients. Katheit $\mathrm{G}$ et al also found that rural and urban patient's ratio was almost equal among urban $(52.4 \%)$ and rural $(47.6 \%){ }^{7}$

Majority of the cases in both groups had 2 children (39\% and $64 \%$ in vaginal and intra cesarean group). Majority of para 2 women in cesarean group prefer PPIUCD because they wanted to avoid any unwanted pregnancy after two operative delivery. Only $10 \%$ of patients were reported in intra cesarean group with para 3 because most of them opted for tubal ligation. Soni $\mathrm{M}$ et al also reported the similar incidence of para 2 in both groups $(26.7 \%$ in vaginal and $68.7 \%$ in intra cesarean group). ${ }^{8}$ Hindu population is more as compared to Muslim is also reflected in present study group.

The cases were followed up to 9 months post delivery. 2 women in vaginal group came early before the scheduled follow up, due to spontaneous and partial expulsion. Out of 100 cases in vaginal group, 70 were followed up in our hospital and 15 were contacted over phone. They had examination at nearby peripheral health services and private hospitals. In cesarean group 72 cases visited our institute whereas 20 cases got examined at private and peripheral hospitals. Overall $85 \%$ cases in vaginal group and $92 \%$ cases in cesarean group returned for follow up. $15 \%$ cases in post placental group were lost in follow up which was slightly higher as compared to intra cesarean group (8\%). This may be because of cesarean patients paid more attention to follow up visits as compared to vaginally delivered. "Insert and report and then forget" that must be replaced by "counsel and report, insert and report and follow up and report" and of course provide service at every visit. Few patients reported before the scheduled visit, mainly with complaints of protrusion of tail at introitus or due to spontaneous expulsion of IUCD. Similar to present study, Katheit $\mathrm{G}$ et al also found that $83.4 \%$ cases returned for follow up and $16.12 \%$ of cases were lost to follow-up. ${ }^{7}$ Mishra $\mathrm{S}$ et al observed that many cases did not return for follow up; $59.98 \%$ visited clinic, another $18.97 \%$ were contacted over phone and $23.05 \%$ were lost to follow up (Table 2). ${ }^{9}$ 
In present study protrusion of tail at introitus was the leading complaint in $14.1 \%$ of post placental group whereas $7.6 \%$ in cesarean group which was statistically not significant $(\mathrm{p}=0.162)$. Irregular bleeding PV was the main complaint in $9.7 \%$ cases of intra cesarean group and slightly lower $5.8 \%$ cases in vaginal group. Various other complaints e.g. heavy bleeding PV, white discharge, pain abdomen, were similar in the both group and managed with proper treatment and assurance. Bleeding problems varies from as high as $23.5 \%$ by Mishra $\mathrm{S}$ et al to as low as $5.5 \%$ minor menstrual problems by Kumar $\mathrm{S}$ at el (Table 3). ${ }^{9,10}$

On per speculum examination, significantly high numbers of missing threads were detected in intra cesarean group $(22.8 \%)$ as compared to $12.9 \%$ in post placental group. Similar to present study Halder at el found $30 \%$ of missing tails in cesarean group, $17.7 \%$ in vaginal group and Hooda $\mathrm{R}$ et al also found high missing tails in cesarean group $(55.1 \%)$ than vaginal group $(22.1 \%)^{6,11}$ This may be because many cesareans were done in latent phase of labor or not in labor cases. Coiling of the CuT thread inside the cavity of uterus may appear due to closed or incompletely dilated internal os. ${ }^{9}$ Coiling of thread also leads to lowered incidence of protrusion of tail at introitus in cesarean group $(7.6 \%)$ versus $(14.1 \%)$ in vaginal group. In contrast to present study Halder et al observed $10 \%$ long strings in intra cesarean group and $6.6 \%$ in post placental group (Table 4 ). ${ }^{6}$

Ultrasonography was required in $27.1 \%$ of cesarean and $12.9 \%$ of vaginal group mainly for missing tails with significant statistical difference $(\mathrm{p}=0.01)$. USG of 25 patients of missing tail in cesarean group revealed that 23 patients had normally placed IUCD, one had displaced and another one had no IUCD due to unnoticed spontaneous expulsion. It was confirmed by X-ray pelvis.

In contrary to this, 11 patients of missing tail in post placental group who underwent USG it was found that 7 had normally placed IUCD and 4 had no IUCD in the uterine cavity (Table 5).

Results of present study showed that spontaneous expulsion in post placental group was $7.0 \%$ whereas it was only $4.3 \%$ in cesarean group cases. Incidence of displaced (partial expulsion) IUCDs was also higher in vaginal group $(8.2 \%)$ compared to cesarean group $(6.5 \%)$. Overall $15.2 \%$ cases in vaginal group and $10.8 \%$ in cesarean group were discontinued IUCD because of expulsion. $14.1 \%$ cases of vaginal group expelled IUCD within 2 months after delivery whereas only $5.8 \%$ expelled in intra cesarean group, which was statistically near significant $(\mathrm{p}=0.06)$.

Higher expulsion rates in post placental group could be related to blind procedure in vaginal deliveries as compared to direct visualization and better fundal placement in cesarean group. Most of the post placental insertion were conducted by resident doctors and trained nursing staff; in contrast to this IUCD placement during cesarean was done under direct visualization and supervision of senior doctors. Similar to present study, Katheit et al found $10.5 \%$ expulsion rate $^{7}$ and Shukla et al also found $10.7 \%$ cumulative expulsion rate by six months in a study of 1317 women in north India.,12 Expulsion rates in various studies were vary in different studies which ranges from $1.6 \%$ among 3000 cases in Paraguay, 5.6\% among 305 women in Zambia' Mishra et al found $6.4 \%$ expulsion at 6 weeks. ${ }^{9,13,14}$ El Beltagy NS et al found that expulsion rates were similar and relatively high in CuT 380 (15\%) and Multiload 375 (14.9\%) (Table 6). ${ }^{15}$

Analysis of various causes for PPIUCD removal revealed that heavy bleeding PV with or without the pain abdomen was the leading cause for removal in present study in both groups. $5.8 \%$ in vaginal group and $5.4 \%$ in cesarean group removed $\mathrm{CuT}$ because of heavy bleeding PV. Another $3.5 \%$ and $3.2 \%$ in vaginal and cesarean group respectively, discontinued IUCD due to heavy bleeding PV associated with pain abdomen. Removal rate for irregular bleeding PV was less in the both groups as they were managed and counseled better.

3 cases $(3.5 \%)$ of post placental group removed $\mathrm{CuT}$ because they were motivated for abdominal sterilization by ASHA (accredited social health activist). Psychosocial reason like failure to gain weight because of $\mathrm{CuT}$ was reason in one case of post placental group for removal. In accordance to present study Soni $\mathrm{M}$ et al also found the heavy BPV (8\%) pain abdomen $(4 \%)$ were two common cause of removal in PPIUCD. ${ }^{8}$ High removal rate was found in vaginal group (15.2\%), as compared to $10.8 \%$ in cesarean group which was not significant statistically $(\mathrm{p}=0.382)$ (Table 7).

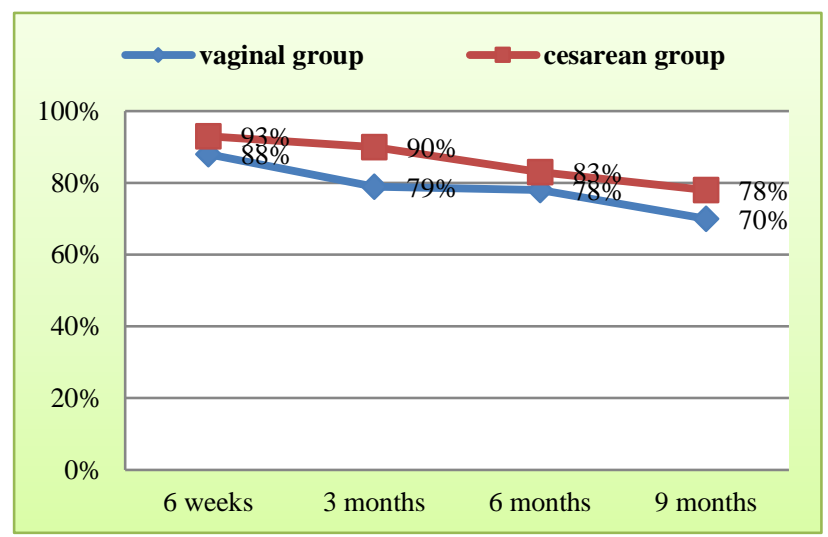

Figure 1: Continuation pattern of PPIUCD.

Similar to various other studies no perforation and no infection was reported in the both groups. ${ }^{7,12}$ This may be due to good selection and better management of the patients. Present study showed continuation rates of $69.4 \%$ in vaginal group and $78.2 \%$ in intra cesarean group over a period of 9 months $(\mathrm{p}=0.180)$ (Table 8). In contrast to this Halder et al found continuation rate of 
$88 \%$ in vaginal group and $94 \%$ in cesarean group at the end of 18 months and S Mishra et al found $91.1 \%$ of continuation rate in their study (Figure 1). ${ }^{6,9}$

\section{CONCLUSION}

From the study results we came to the conclusion that PPIUCD is very effective, safe, and reversible contraceptive method which provides contraceptive effect soon after birth. Especially in those patients who have limited access to health care facilities and infrequent post partum care, this method can be considered as the best for them. Although there is relatively higher incidence of expulsions in the both groups $(10.8 \%-15.2 \%)$ as this also denotes that retention rate is about $(84.8 \%-89.2 \%)$ even than must be encouraged for various advantages of PPIUCD. Acceptance (11\%) is still low even after providing incentives to the providers as well as ASHA. This may be because counseling for PPIUCD was done mostly in labor room that must be started during ANC or by ASHA and MPHW-F (Multipurpose health workerfemale). Misconceptions and myths regarding CuT are very much prevalent in this southern part of Rajasthan. Government needs to develop strategies to increase public awareness of the PPIUCD and to resolve the myths regarding $\mathrm{CuT}$ by using different media sources.

\section{ACKNOWLEDGMENTS}

Authors would like to thank Department of Obstetrics and Gynecology, RNT Medical College, Udaipur, Rajasthan and to the clients for their co-operation.

Funding: No funding sources

Conflict of interest: None declared

Ethical approval: The study was approved by the Institutional Ethics Committee

\section{REFERENCES}

1. Post-partum IUCD reference manual; Family Planning Division. Ministry of Health and Family Welfare, Government of India; 2010: 1-3

2. Park K. Social and Preventive medicine 22nd ed. Jabalpur. Banarsidas Bhanot;2013:471-2.

3. World Health Organization. Medical Eligibility Criteria for contraceptive use: a WHO family planning cornerstone. 4th ed. Geneva: World Health Organization;2010:3-4

4. Grimes D, Lopez LM, Schulz KF, Stanwood NL. Immediate postpartum insertion of intrauterine devices. Cochrane Database Syst. Rev. 2010;12:CD003060.
5. Bluestone J, Chase R, Lu ER. USAID IUD guideline for family planning services programme $3^{\text {rd }}$ edition. A Problem-solving Reference Manual;2008.

6. Halder A, Sowmya MS, Gayen A, Bhattacharya P, Mukherjee S, Datta S. A prospective study to evaluate vaginal insertion and aintra cesarean insertion of post-partum intrauterine contraceptive device. J Obstet Gynecol India. 2016;66(1):35-41.

7. Katheit G, Agarwal J. Evaluation of PPIUCD in terms of awareness, acceptance and expulsion in a tertiary care center. Int J Reprod Contracept Obstet Gynecol. 2013;2:539-543.

8. Soni M, Sharma V, Bhat MP, Sharma A. Postplacental postpartum intrauterine contraceptive devices insertion: our scenario. Int J Reprod Contracept Obstet Gynecol. 2016;5:766-9.

9. Mishra S. Evaluation of safety, efficacy and expulsion of post-placental and intra-cesarean insertion of intrauterine contraceptive devices (PPIUCD). J. Obstet. Gynaecol. India. 2014 Oct; 64(5):337-43.

10. Kumar S, Sethi R, Balasubramaniam S, Charurat E, Lalchandani K, Semba R, et al. Women's experience with postpartum intrauterine contraceptive devices use in India. Reprod Health. 2014;11:32.

11. Hooda R, Mann S, Nanda S, Gupta A, More H, Bhutani J. Immediate postpartum intrauterine contraceptive device insertions in caesarean and vaginal deliveries: a comparative study of follow-up outcomes. Int J Reproduc Med. 2016 Aug 17;2016.

12. Shukla M, Qureshi S, Chandrawati. Post placental Intrauterine device insertion. A five year experience at a tertiary care center in north India. Indian J Med Res. 2012;136:432-5.

13. Araujo VB, Ortiz L, Smith J. Postpartum IUD in Paraguay: A case series of 3000 cases. Contraception. 2012;86:173-186.

14. Blumenthal P, Shiliya N, Neukom J, Chilambwe J, Vwalika B, Prager B at al. Expulsion rates and satisfaction levels among immediate post partum IUD user in peri-urban Lusaka, Zambia. Contraception. 2011;84:320.

15. El Beltagy NS, Darwish EA, Kasem MS, Hefila NM. Comparison between Cupper T380 IUD and Multiload 375 IUD in early post partum insertion. Middle East Fertil Soc J. 2011 Jun 30;16(2):143-8.

Cite this article as: Kanwat B, Salodia L, Chauhan M, Rastogi R. Comparative study of post-partum intrauterine contraceptive device in vaginal and intra caesarean insertion. Int J Reprod Contracept Obstet Gynecol 2017;6:4938-44. 